\title{
Mendorong Semangat Inklusifisme dan Toleransi:
Studi atas Buku Daras Pendidikan Agama Islam (PAI)
dan Model Pembelajarannya di Universitas Brawijaya Malang \\ Media Zainul Bahri \\ UIN Syarif Hidayatulah Jakarta \\ zainul.bahri@uinjkt.ac.id
}

\begin{abstract}
This article explores the insights of inclusivism and tolerance in Islamic religious education (PAI) textbooks in Brawijaya University (UB) Malang. This article is the result of research by reading textbooks, interviewing six PAI lecturers and focus group discussions (FGD) at UB Malang in December 2018. In general, there are many material aspects in the textbooks that encourage students to be open, respect for diversity and behave tolerant of different Islamic schools of thought. This is emphasized by the PAI lecturers since UB is a public university belong to the public and because in Islam itself there are many different understandings and schools of thought. The spirit of inclusivism, cosmopolitan and tolerance is seen explicitly in PAI UB's textbooks and becomes the vision of PAI lecturers. If there is a deviation from the book tends to be a closed ideology, intolerant, and against the Republic of Indonesia, then it can be ascertained because of the "lecturer initiative" personally, and do not represent Lembaga Pusat Pembinaan Agama (the Central Institution of Religious Development).
\end{abstract}

Keywords: Textbooks, Educational Institutions, Learning, Understanding Religion.

\begin{abstract}
Abstrak: Artikel ini menelusuri wawasan inklusifisme dan toleransi dalam buku ajar Pendidikan Agama Islam (PAI) di Universitas Brawijaya (UB) Malang. Artikel ini merupakan hasil riset dengan cara membaca buku daras, mewawancarai enam dosen PAI dan focus group discussion (FGD) di UB Malang pada Desember 2018. Secara umum ditemukan banyak sekali aspek atau materi dalam buku daras yang mendorong mahasiswa bersikap terbuka, menghormati kemajemukan dan bersikap toleran terhadap orang lain dengan paham/mazhab yang berbeda. Hal ini ditegaskan oleh para dosen PAI dengan alasan karena UB adalah perguruan tinggi umum negeri milik publik dan karena dalam Islam sendiri memang terdapat banyak paham dan mazhab yang berbeda-beda. Semangat inklusifisme, kosmopolitan dan toleransi terlihat eksplisit dalam buku daras PAI UB dan menjadi visi para dosen PAI. Jika terjadi penyimpangan dari buku daras tersebut atau ada ideologi tertutup, ideologi takfiri yang intoleran, ideologisasi Islam yang melawan NKRI, maka bisa dipastikan hal itu karena "inisiatif dosen" secara personal, dan tidak mewakili Lembaga Pusat Pembinaan Agama (PPA).
\end{abstract}

Kata Kunci: Buku Teks/Daras, Lembaga Pendidikan, Pembelajaran, Pemahaman Agama. 


\section{Pendahuluan}

Riset ini berfokus pada buku teks Pendidikan Agama Islam (PAI) Universitas Brawijaya (biasa disingkat UB) disertai dengan pandangan para dosen PAI tentang model pengajaran dan beberapa isu aktual keislaman yang relevan. Pendidikan agama Islam di Universitas/Perguruan Tinggi Umum (PTU) di Indonesia mungkin telah dimulai sejak akhir 1960-an, terutama setelah pemberontakan PKI pada 1965. Dalam catatan Mukti Ali, selain karena kondisi keagamaan masyarakat Indonesia yang sangat kental dengan fikih dan mistik, peristiwa pemberontakan PKI pada 1965 seolah membangunkan semangat dakwah Muslim Indonesia menjadi semakin tinggi dan menguat karena komunisme dianggap identik dengan ateisme, dan ateisme harus dilawan. ${ }^{1}$ Dalam konteks inilah pembelajaran agama Islam di Perguruan tinggi umum digalakkan, dan tentu saja dalam semangat "dakwah dan memperkuat iman". Pada awal hingga pertengahan tahun 1970-an ketika studi Islam mulai 'ramai' di PTU dengan berbagai metodologinya dan karena ada figur-figur seperti HM Rasyidi, Endang Saifuddin Anshari, Sidi Gazalba, Imaduddin Abdul Rahim, Hasbullah Bakrie dan lain-lain, konteks "dakwah dan memperkuat iman" tidak pernah hilang dari materi dan metodologi studi Islam tersebut. Artinya, pada masa-masa itu, bahkan hingga kini, Pendidikan agama Islam di PTU hanya sedikit saja yang bercorak critical thinking. Keadaan itu memang dapat dimaklumi.

Dalam Kata Sambutannya, Rektor UB, Prof. Dr. Ir. Yogi Sugito, menyampaikan amanat UU No. 2 tahun 1989 bahwa tujuan Pendidikan nasional adalah "untuk mencerdaskan kehidupan bangsa dan mengembangkan manusia Indonesia seutuhnya, yaitu manusia yang beriman dan bertakwa kepada Tuhan YME, berbudi pekerti luhur, memiliki pengetahuan dan keterampilan, kesehatan jasmani dan rohani, kepribadian yang mantap dan mandiri serta rasa tanggung jawab kemasyarakatan dan kebangsaan", dan karena tujuan inilah maka Pendidikan agama di UB sangat penting. ${ }^{2}$ Urgensi PAI ini kemudian dikukuhkan oleh UU No. 12, tahun 2012 tentang Pendidikan Tinggi yang menyatakan bahwa pembelajaran di perguruan tinggi wajib menyelenggarakan mata kuliah Agama, Pancasila, Pendidikan Kewarganegaraan, dan Bahasa Indonesia. $^{3}$

Riset ini sejatinya hendak melihat sejauhmana buku daras atau buku teks PAI UB mendorong mahasiswa menjadi manusia beragama yang terbuka, toleran, memiliki semangat menghargai perbedaan, dan bersikap kosmopolit. Bersamaan dengan hal itu, riset ini juga mau melihat apakah materi-materi dalam buku teks PAI UB mengandung pembelajaran yang mendorong para 
mahasiswa menjadi "radikal", atau anti negara-bangsa Indonesia, atau anti demokrasi yang dianut Indonesia, atau memiliki paham terorisme.

Untuk kepentingan riset tersebut, saya dibantu oleh Asisten Peneliti (lokal), Ary Budiyanto MA (dosen tetap FIB UB), meneliti satu buku daras primer PAI UB berjudul "Buku Daras Pendidikan Agama Islam Di Universitas Brawijaya" (PPA, 2015), dan satu buku ajar sekunder "LBGT Dalam Tinjauan Fikih” karya Rozikin (UB Press, 2017). Untuk mengeksplorasi model dan proses pembelajaran serta referensi para dosen yang mengajar, kami mewawancarai 5 orang dosen (secara terpisah) pada 12 Desember hingga 15 Desember 2018, yakni: Khalid Rahman MA, In'amul Wafi MA, Ahmad Muhajir M.Pdi, Sugeng Santoso M.Pd, dan Siti Rohmah M.Hi. Pada 13 Desember 2018, kami mengadakan FGD dengan mengundang lima (5) dosen di atas (secara bersamaan) dan satu (1) dosen PAI di Sekolah Tinggi Agama Buddha Kertarajasa, Batu-Malang, Ibu Latifah sebagai perbandingan dari model studi PAI pada agama Buddha.

Karena riset ini fokus pada teks buku daras PAI UB, maka saya menggunakan pendekatan hermeneutik rekonstruksi. Schleiermacher mendefinisikan hermeneutik sebagai seni memahami (hermeneutics as the art of understanding). Hermeneutik merupakan pengetahuan mengenai cara memahami dan menafsirkan (interpretasi), sedangkan rekonstruksi berarti membangun kembali. Dengan demikian, hermeneutik rekonstruksi adalah membangun kembali pemahaman atau penafsiran atas (makna) teks seperti yang dimaksud oleh pengarangnya, dan bukan membuat makna baru yang berbeda dengan apa yang dimaksud oleh penulis teks. Jadi, semaksimal mungkin saya akan menelusuri makna gramatikal dan makna psikologis sang pengarang teks untuk "membangun kembali" pengertian, pandangan atau maksud sang pengarang teks tentang teks yang ditulisnya.

\section{Regulasi dan Tujuan Pembelajaran PAI}

Pembelajaran PAI di UB berada di bawah koordinasi Pusat Pembinaan Agama (disingkat PPA) UB, yang mengelola semua Pendidikan agama (Islam, Kristen, Katolik, Hindu, Buddha, dan Konghucu) di UB. Mata kuliah PAI di UB Bersama-sama dengan mata kuliah Pancasila dan Bahasa Indonesia disebut dengan MPK, Mata Kuliah Pengembangan Kepribadian. Tim dari MPK ini mengurusi semua persoalan perkuliahan MPK, termasuk merancang silabus. Sementara PPA sebenarnya adalah Lembaga non-struktural yang mengurusi semua kegiatan non-akademik dan mengembangkan semua kajian agama-agama yang dianut oleh para mahasiswa. 
Dosen tetap PAI UB seluruhnya berjumlah 12 orang. Yang bersedia diwawancarai dalam riset ini 5 orang: Khalid Rahman MA, In'amul Wafi MA, Ahmad Muhajir M.Pdi, Sugeng Santoso M.Pd, dan Siti Rohmah M.Hi. MK PAI biasanya diajarkan pada semester I (semester ganjil), meskipun ada juga Fakultas yang baru menawarkan di semester genap/semester II. Pada semester ganjil, yakni semester pertama bagi mahasiswa baru terdapat 400 kelas untuk PAI. Jika ini yang terjadi maka PPA meminta bantuan kepada UIN Malang sebanyak 7 orang sebagai dosen honorer. Ketua PPA UB adalah Prof. Dr. Thohir Luth, seorang dosen senior atau pinisepuh UB, dan satu-satunya dosen PAI yang jadi Profesor di Fakultas Hukum UB dengan spesialisasi Hukum Islam. Semua dosen PAI yang tergabung dalam PPA UB juga menjadi bagian yang resmi dari ADPISI, Asosiasi Dosen Pendidikan Agama Islam Indonesia. ADPISI ini organisasi profesi di bawah Dirjen Pembelajaran PAI KemenristekDikti.

Dosen-dosen PAI UB mengetahui "Buku Ajar Pendidikan Agama Islam untuk Perguruan Tinggi Umum (2016)" (disingkat PAI-UPT) yang ditulis oleh Tim dari ADPISI karena beberapa dosen ikut dalam workshop penyusunan buku tersebut. Tetapi ada beberapa hal yang membuat buku tersebut tidak menjadi buku pedoman/ajar di PAI UB. Pertama, ADPISI sendiri tidak "mewajibkan” buku tersebut. PTU diberi keleluasaan untuk melakukan impro-visasi dalam membuat buku ajar sendiri, tetapi secara umum tetap mengikuti garisgaris besar/pokok dalam buku tersebut. Kedua, masing-masing PTU me-miliki kekhasan/uniqueness. Ketiga, menurut Khalid Rahman, Kabid Agama Islam PPA, Prof. Thohir Luth menilai bahwa buku tersebut kental "berwarna hijau" (NU), sedangkan Thohir Luth sendiri benderanya berwarna "Biru" (Muhammadiyah). Karena persoalan ideologis ini, ia kurang berkenan atas buku itu.

Pada Oktober 2005, Tim dosen PAI UB menerbitkan buku pertama kali berjudul "Buku Daras Pendidikan Agama Islam Di Universitas Brawijaya", diterbitkan oleh UB Press. Pada September 2015 buku ini sudah cetak yang kesepuluh kali. Jika melihat konten dari buku daras tersebut, bisa dipahami kiranya bahwa buku PAI-UPT produk ADPISI telah melihat atau mempertimbangkan buku-buku daras PAI yang telah lama/lebih dahulu terbit di PTUPTU di banyak tempat di tanah air. Karena itu, menurut In'amul Wafi--dan setelah dicocokkan, terdapat banyak sekali kemiripan/kesamaan substansi materi buku ajar PAI-UPT versi PAI-UPT ADPISI dengan buku daras PAI UB. Pada PAI-UPT bab "Bagaimana manusia bertuhan" sama dengan bab I dan bab II. Bab "Bagaimana Agama menjamin kebahagiaan" sama dengan gabungan bab I dan V. Bab "Bagaimana membangun paradigma Qurani" sama dengan bab VI 
dan VII. Bab "Bagaimana Membumikan Islam di Indonesia" sama dengan bab VIII. Bab "Bagaimana Islam membangun persatuan dalam keberagaman" sama dengan bab IX. Bab "Bagaimana Islam menghadapi tantangan modernisasi" sama dengan bab X dalam buku daras. Berdasarkan banyak kesamaan substansi dari keduanya, Wafi membuat istilah "Nyanyiannya sama, iramanya yang berbeda".

Hal yang paling penting dan fundamental adalah bahwa buku daras PAI UB adalah buku wajib, buku acuan, atau buku yang telah disepakati untuk jadi "pedoman" para dosen PAI, meskipun --menurut pengakuan para dosen yang kami wawancarai-- para dosen boleh berimprovisasi sejauh tidak bertentangan denga isi dan substansi buku daras yang telah disusun. Buku-buku atau referensi tambahan (sekunder) dari para dosen (1) tidak boleh terlalu jauh dari "buku daras wajib” yang bisa menyebabkan mahasiswa kesulitan memahami, atau (2) bertentangan deng isi buku daras yang membuat visi dan substansi/isi buku daras tidak sampai kepada mahasiswa.

Selain memakai buku daras, Tim PPA yang bergabung ke dalam tim MPK kemudian merancang RPS (Rencana Pembelajaran Semester) PAI untuk semua Fakultas, kecuali Fakultas Kedokteran yang memiliki beberapa muatan khusus (Islam dan dunia medis/kedokteran). Dalam RPS disebutkan bahwa Tujuan pembelajaran PAI di UB berisi empat (4) hal pokok, yakni (A) Sikap Spiritual: Menghayati dan mengamalkan ajaran Islam yang dianutnya sebagai pola hidup dalam konteks akademik dan/atau profesi; (B) Sikap Sosial: Mengembangkan perilaku (jujur, disiplin, tanggung jawab, peduli, santun, ramah lingkungan, gotong royong, kerja sama, cinta damai, responsif dan proaktif); (C) Pengetahuan: Memahami, menerapkan, menganalisis, mengevaluasi, dan mencipta pengetahuan faktual, konseptual, prosedural, dan metakognitif dengan wawasan kemanusiaan, kebangsaan, kenegaraan, dan peradaban terkait berbagai fenomena dan kejadian, serta menggunakan pengetahuan prosedural pada bidang kajian keislaman sesuai dengan bakat dan minat; (D) Keterampilan: Mengolah, menalar, mencipta, dan menyaji berbagai hal dalam ranah konkret dan abstrak secara mandiri; serta bertindak secara efisien, efektif, dan kreatif; serta menggunakannya sesuai kaidah keilmuan Islam dan/atau keprofesionalan. Tujuan pembelajaran ini kiranya sama atau menyesuaikan dengan model RPS yang dibuat secara nasional.

\section{Temuan Hasil Penelitian dan Analisis}

Buku Daras Pendidikan Agama Islam UB terdiri dari 12 (dua belas) bab, yaitu: (1) Pemahaman Makna Agama; (2) Konstruksi Pemahaman Ketuhanan 
dalam Islam; (3) Petunjuk Islam tentang Alam Semesta; (4) Pandangan Islam tentang Manusia; (5) Implementasi Iman \& Takwa dalam Kehidupan Modern; (6) Pemahaman dan Penerapan Hukum Islam; (7) Aktualisasi Akhlak dalam Kehidupan Muslim; (8) Masyarakat Madani \& Kerukunan Umat Beragama; (9) Pandangan Islam tentang Kebudayaan; (10) Pandangan Islam tentang IPTEK dan Seni; (11) Pandangan Islam tentang Ekonomi; dan (12) Pandangan Islam tentang Politik. Saya hanya akan mendiskusikan beberapa hal pokok yang saya anggap merepresentasikan substansi atau ruh dari model buku daras PAI UB, dalam arti sejauhmana buku daras itu membuka cakrawala, memperkuat iman, mengasah nalar, dan mendorong para mahasiswa untuk mengapresiasi perbedaan dan menolak radikalisme keagamaan. Beberapa hal yang penting itu antara lain: (1) cara memahami makna agama; (2) Ajaran tauhid, (3) Pemahaman Hukum Islam; (3) Masyarakat Madani dan Kerukunan Umat Beragama; (4) Misi Perdamaian dan Kerahmatan Islam Bagi Seluruh Alam; (5) Kebersamaan Dalam Pluralitas Agama; dan (6) Kebudayaan Dalam Islam. Mari kita lihat satu per-satu.

\section{Memahami Makna Agama}

Buku daras memulai dengan pernyataan bahwa pencarian makna agama bukan suatu persoalan yang mudah, apalagi membuat definisi yang dapat menampung semua persoalan esensial yang terkandung dalam agama. Ada beberapa cara yang dilakukan para ahli dalam menyoroti agama. Sudah dapat dipastikan pendekatan-pendekatan yang dilakukan mereka diwarnai oleh latar belakang pemikiran bidang yang mereka geluti, termasuk di dalamnya para ahli yang mengkhususkan pada agama-agama tertentu. ${ }^{4}$

Agama dalam beberapa permikiran yang berkembang di Barat sering dilihat dari segi fenomena yang ditampilkan oleh para pelaku atau penganut agama. Hal ini sesuai dengan metode yang mereka kembangkan yang lebih cenderung memandang realitas sebagai sesuatu yang tampak, jadi agama pun dilihat sebagai apa yang tampak dalam tingkah laku penganut agama. ${ }^{5}$

Pendekatan terhadap agama yang dilakukan oleh para ahli psikologi adalah dengan melihat hubungan atau dorongan-dorongan antara apa yang ada di dalam diri indvidu dengan lingkungan di luar dirinya. Misalnya Sigmund Freud, memandang bahwa agama berasal dari ketidakmampuan (helplessness) manusia menghadapi kekuatan alam di luar diri dan juga kekuatan insting dari dalam diri. Munculnya agama pada tingkat pertama perkembangan manusia, disaat manusia belum mampu menggunakan akal untuk mengatasi kekuatan yang ada di luar dan di dalam diri dan harus menghadapi atau mengatur dengan 
bantuan kekuatan lain yang lebih efektif. Freud melihat agama sebagai fenomena manusia primitif atau paling tidak dalam taraf perkembangan masa kanak-kanak (the childhood of man). Agama dipandang sebagai ilusi atau imajinasi anak-anak yang penuh fantasi dan mimpi. Pandangan Freud semacam ini menyebabkan ia dituduh sebagai anti agama. ${ }^{6}$

Sebaliknya, Carl Gustav Jung, salah seorang murid Freud, dipandang sebagai orang yang memihak agama. Ia berpendapat bahwa hakikat dan pengalaman keagamaan adalah ketundukkan pada kekuatan yang lebih tinggi daripada kekuatan kita sendiri. Pengalaman keagamaan, menurut Jung, merupakan ketidaksadaran yang disebabkan oleh kekuatan di luar diri yang disebutnya sebagai ketidaksadaran agamis. Salah satu pandangan Jung yang patut menjadi catatan adalah bahwa agama dalam pandangannya merupakan fenomena yang lahir dari ketidaksadaran. ${ }^{7}$

Selanjutnya, agama dalam pandangan para sosiolog dianggap sebagai suatu fenomena sosial dengan melihat kelembagaan suatu agama dan perilaku para pemeluk agama. Menurut Emile Durkheim, agama adalah suatu kesatuan sistem kepercayaan dan pengalaman terhadap sesuatu yang sakral, yaitu yang lain daripada yang lain: kepercayaan dan pengalaman yang menyatu ke dalam suatu komunitas moral yang disebut gereja. Dalam pandangan ini agama hanya dilihat sebagai suatu komunitas moral, padahal moral hanya merupakan salah satu dimensi dalam agama. Di sini Durkheim melihat agama dari sudut sosial, baik dalam bentuk kepercayaan maupun pengalaman. Oleh karena itu, definisi agama di atas tidak dapat mewakili pengertian agama secara keseluruhan. Karena esensi dari agama sendiri tidak disentuh sama sekali. ${ }^{8}$

Pemikiran yang lain tentang agama dapat dilihat melalui pikiran yang berkembang di kalangan para ahli yang dipengaruhi oleh pikiran Charles Darwin tentang evolusi. Di kalangan ini ada keyakinan bahwa agama pada dasarnya berevolusi sesuai dengan tingkat budaya yang dicapai manusia. Tylor menyatakan bahwa agama berkembang melewati beberapa fase, yaitu fase dinamisme, politeisme, dan monoteisme. Fase dinamisme adalah tahap paling primitif di mana manusia memercayai akan adanya kekuatan-kekuatan yang dikandung oleh alam atau barang-barang tertentu yang masing-masing memiliki kekuatan-kekuatan yang dipegang oleh dewa-dewa tertentu. Kepercayaan ini merupakan implikasi dari ketergantungan manusia terhadap alam dan sikapnya yang menyesuaikan terhadap alam sebagai salah satu ciri dari masyarakat primitif. Tahap poleteisme adalah pengembangan dari pikiran manusia yang berawal dari dinamisme tetapi lebih maju, di mana kekuatan-kekuatan itu mulai terorganisasi dan terstruktur dalam bentuk kekuatan-kekuatan yang 
dipegang oleh para dewa tertentu. Tahap monoteisme adalah tahap baru yang didasarkan kepada perkembangan akal dan budaya manusia yang semakin maju, di mana kekuatan Tuhan terpadu pada satu zat yang maha berkuasa. ${ }^{?}$

Lebih jauh, Auguste Comte (1778-1857) melihat agama sebagai persoalan yang ada di kalangan masyarakat tingkat pertama atau masyarakat primitif yang kemudian meningkat kepada tahap kedua, yaitu tahap metafisik sampai akhirnya manusia mencapai tingkat positif. Maksudnya, tingkatan ilmu pengetahuan (sains) yang di dalamnya manusia tidak lagi suka memikirkan apa yang tidak dapat mereka cobakan, akan tetapi manusia membatasi dan mendasarkan pengetahuannya kepada apa yang dapat dilihat (observable), apa yang dapat diukur (measurable), dan apa yang dapat dibuktikan (verifiable). Dalam pandangannya, agama merupakan persoalan magis dan mistik yang hanya ada dan cocok bagi masyarakat primitif. ${ }^{10}$

Terlepas dari pandangan Comte, pencarian makna agama yang dapat merangkum semua agama mengalami kesuitan bahkan dipandang sebagai suatu upaya yang tidak mungkin dapat dilakukan, karena agama merupakan sesuatu yang bersifat subjektif, yang menyangkut kepentingan mutlak seseorang yang dipengaruhi oleh tujuan orang yang mendifinisikannya. Para ahli mendefinisikan agama dari sudut pandang latar belakang masing-masing.

Oleh karena pencarian makna agama yang mencakup pengertian yang dapat diterima oleh semua agama adalah suatu yang mustahil, maka pengertian agama dalam bagian ini merujuk pada pengertian agama dalam pandangan agama Islam, yaitu "ketentuan ketuhanan yang mengantarkan manusia kepada kebahagiaan dan kesejahteraan di dunia dan akhirat, dengan berpegang teguh kepadanya".

Kendati demikian, ada bentuk-bentuk dan ciri-ciri khas yang biasanya ada dalam kepercayaan-kepercayaan dan aktifitas keagamaan yang ada pada setiap agama dan dipandang sebagai ciri khas keagamaan yang secara langsung atau tidak langsung ada atau berlaku dalam suatu agama. Ciri-ciri tersebut adalah kebaktian, pemisahan antara sakral dan profan, kepercayaan terhadap jiwa, kepercayaan terhadap dewa-dewa atau Tuhan, penerimaan atas wahyu yang supranatural dan pencarian keselamatan. ${ }^{11}$

Agama bagi manusia, sebagaimana aspek kebutuhan lainnya, memiliki peran dan fungsi tertentu dalam memenuhi hajat hidup. Ada dua macam fungsi agama, yakni fungsi maknawi, dan fungsi identitas. Max Weber memandang fungsi maknawi sebagai dasar bagi semua agama. Agama menyajikan wawasan dunia atau kosmos, karenanya segala ketidakadilan, penderitaan, dan kematian dapat dipandang sebagai suatu yang penuh makna. Termasuk ke dalam makna 
ini antara lain konsep, ide, tuntutan dan kewajiban. Filsafat juga menyajikan wawasan kosmik, tetapi tidak tertuju pada emosi manusia secara mendalam, karena itu kurang mendorong manusia untuk menyadari bahwa mereka dikuasai sistem kepercayaan, tetapi agama melalui konsep ritual menjalin dimensi afektif dan kognitif, dan jawaban agama senantiasa berurusan dengan nilai. ${ }^{12}$

Agama dilihat dari asal tumbuhnya menurut pandangan masyarakat umumnya yang banyak dipengaruhi oleh pemikiran Barat mencakup berbagai kepercayaan yang lahir melalui ide, pikiran, atau gagasan manusia dalam bentuk budaya dan agama yang lahir dari wahyu. Para pemikir Barat seringkali menyamakan begitu saja agama yang lahir dari budaya dan agama wahyu. Padahal kedua hal tersebut mengandung perbedaan yang sangat esensial dan sekaligus pula mengandung implikasi yang sangat berbeda.

Dalam al-Qur'an, agama disebut millah, misalnya millatu Ibrähìm yang artinya agama (yang dibawa) Ibrāhīm (QS. al-Naḥl [16]: 123). Selain itu, dalam al-Qur'an agama disebut juga dīn atau al-Dinn. Misalnya, lakum dinnkum waliya din, yang artinya "bagimu din (agama)mu, dan bagiku din (agama)ku" (alKāfirūn [109]: 6). Selain berarti agama, kata dīn juga berarti: "pembalasan di hari kiamat, adat kebiasaan, undang-undang, peraturan, dan ketaatan. ${ }^{13}$

Agama adalah suatu sistem nilai yang diakui dan diyakini kebenarannya dan merupakan jalan ke arah keselamatan hidup. Sebagai suatu sistem nilai, agama meliputi tiga persoalan pokok, yaitu: ${ }^{14}$

1. Tata keyakinan atau kredo, yaitu bagian dari agama yang paling mendasar berupa keyakinan akan adanya sesuatu kekuatan supranatural, Dzat Yang Maha Mutlak di luar kehidupan manusia;

2. Tata peribadatan atau ritus, yaitu tingkah laku dan perbuatanperbuatan manusia dalam berhubungan dengan dzat yang diyakini sebagai konsekuensi dari keyakinan akan keberadaan Dzat Yang Maha Mutlak;

3. Tata aturan, kaidah atau norma-norma yang mengatur hubungan manusia dengan manusia, atau manusia dengan alam lainnya sesuai dengan keyakinan danperibadatan tersebut.

Agama mengandung empat macam unsur: $:^{15}$

1. Merupakan jalan hidup (way of life). Suatu jalan muamalah yang konkret. Ia memiliki aturan-aturan tertentu sebagai pedoman bagi amal kehidupan penganut-penganutnya.

2. Mengajarkan kepercayaan (keimanan) adanya Tuhan Yang Mah Esa. Tuhan itu mustahil tidak ada, dan mustahil jumlahnya berbilang. 
3. Mempunyai kitab suci yang merupakan kumpulan wahyu yang diterima oleh Nabinya dari Tuhan Yang MahaEsa itu, dengan melalui bisikan Roh Suci (Malaikat Jibril).

4. Dipimpin oleh seorang Nabi. Kalau nabi itu masih hidup, beliau tidak sembunyi di lingkungan orang-orang awam yang bodoh, tetapi menyebarkan ajarannya dengan terbuka, dan sanggup berdiskusi di tengah orang-orang pandai. Kalau nabi itu sudah wafat, maka ada bukti-bukti yang terang bahwa beliau pernah hidup, mengatakan ini dan itu guna petunjuk bagi umatnya.

Dilihat dari sifat dan sumbernya, agama dapat diklasifikasikan kepada tiga kategori, yaitu: (1) agama wahyu dan bukan wahyu; (2) agama misionari dan bukan misionari; dan (3) agama ras geografis dan agama universal. ${ }^{16}$

Jelaslah, bagi buku daras dan para dosen PAI, agama sangat penting dalam kehidupan manusia. Sehingga, diakui atau tidak, sesungguhnya manusia sangatah membutuhkan agama. Sangat dibutuhkannya agama oleh manusia, tidak saja di masa primitif sewaktu ilmu pengetahuan belum berkembang, tetapi juga di zaman modern sekarang sewaktu ilmu dan teknologi telah demikian maju. Agama dianggap sangat penting dalam kehidupan manusia, antara lain dikarenakan agama merupakan: (1) sumber moral; (2) petunjuk kebenaran; (3) sumber informasi tentang masalah metafisika; dan (4) bimbingan rohani bagi manusia, baik di kala suka maupun duka. ${ }^{17}$

Terdapat beberapa hal yang menarik ketika buku daras ini mendiskusikan pengertian dan ciri-ciri agama. Buku itu memulai dengan menyebut tradisi pemikiran Barat, maksudnya para sarjananya, tentang pemahaman agama yang biasanya disandarkan kepada "perilaku beragama", atau dalam pengertian lain “agama historis" atau agama yang dipraktikkan, bukan "agama ideal”. Buku itu seolah ingin membantah tradisi Barat bahwa dalam Islam agama itu pertamatama harus dipahami sebagai "yang sakral”, yang datang dari Tuhan. Memahami agama hanya dari sisi sosiologis atau antropologis, akan mereduksi pengertian agama. Tetapi, hal yang menarik kemudian, buku itu mendiskusikan pandangan para sarjana Barat seperti Freud, Gustav Jung, Comte, Durkheim, Weber, Charles Darwin dan EB Taylor tentang fenomena keagamaan. Hal itu menarik karena beberapa alasan. Pertama, buku itu sudah "sadar" akan diskursus studi Perbandingan Agama, atau sekarang dipanggil dengan nama Studi Agama-agama. Disiplin ilmu ini selalu menyebut nama-nama sarjana di atas ketika mendiskusikan pengertian agama. Tim penulis buku sudah memahami bahwa pembelajaran agama Islam di Perguruan Tinggi harus lebih "ilmiah" atau lebih tinggi derajatnya dari sekolah menengah umum (SMU), karena itu diskur- 
sus para sarjana Barat penting dikemukakan. Kedua, ketika membicarakan ciriciri suatu agama, terlihat bahwa buku daras itu menyandarkan pandangannya pada model Studi Agama sarjana Eropa Barat atau model sarjana Muslim masa Orde Baru yang membuat "kategori agama" berdasar agama mayoritas atau agama besar. Ketika membicarakan macam-macam pengertian Din dalam alQur'an, buku itu tidak mengeksplorasi pandangan para mufasir Muslim.

Meski demikian, buku daras ini mengajak para mahasiswa membuka cakrawala dan wawasan pengertian agama berdasar kajian-kajian ilmiah para sarjana Barat. Pandangan para sarjana Barat juga terlihat menonjol pada pembahasan soal "Konstruksi Pemahaman Ketuhanan Dalam Islam" dan "Petunjuk Islam tentang Alam Semesta", yang kemudian dibandingkan dengan ayat-ayat al-Qur'an dan beberapa pandangan sarjana Muslim.

\section{Ajaran Tauhid}

Hampir semua kajian, diskusi, dan materi buu adaras agama Islam pasti membicarakan soal Tauhid. Seperti pada umumnya, buku daras mengartikan Tauhid sebagai "meng-Esakan Allah", kalimatnya adalah "Là ilāha illallāh", menurut Ibnu Qayyim al-Jawzī, kalimat tersebut disebut sebagai "Kalimat Wahdah", yakni kalimat satu yang menjadi misi utama seluruh Nabi dan Rasul diutus ke muka bumi ini. ${ }^{18}$

Ajaran Tawhīd adalah ajaran sepanjang sejarah manusia, ajaran dari tiaptiap Nabi dan Rasul. Sejak dari Nabi Ādam as., Idris as., Nūh as., Ibrāhīm as., Mūsā as., Daud as., 'İsa as. sampai pada zaman Nabi Muhammad saw.

"Dan Kami tidak mengutus seorang rasul pun sebelum kamu melainkan Kami wahyukan kepadanya: "Bahwasannya tidak ada Tuhan (yang hak) melainkan Aku, maka sembahlah olehmu sekalian akan Aku." (QS. alAnbiyā' [21]: 25)

Tauhid adalah awal dan akhir dari seruan Islam. Ia adalah suatu kepercayaan kepada Tuhan Yang Maha Esa (faith in the unity of God). Suatu kepercayaan yang menegaskan bahwa hanya Tuhanlah yang menciptakan, memberi hukum-hukum, mengatur dan mendidik alam semesta ini (Tawhīd Rubūbiyah). Sebagai konsekuensinya, maka hanya Tuhan itulah satu-satunya yang wajib disembah, dimohon petunjuk dan pertolongannya, serta yang harus ditakuti (Tawhìd Ulühiyah). Bahwa Tuhan itu Zat yang luhur dan segala-galanya, Hakim Yang Maha Tinggi, yang tiada terbatas, yang Kekal, yang tiada berubahubah, yang tiada kesamaannya sedikit pun di alam ini, sumber segala kebaikan dan kebenaran, Yang Maha Adil dan Suci, Tuhan itu bernama Allah swt. ${ }^{19}$ 
Lawan dari tawhìd ialah syirik, yaitu mempersekutukan Tuhan. Suatu kepercayaan tentang adanya lagi tuhan selain Allah swt. Kepercayaan syirik ini adalah dosa besar di sisi Allah: ${ }^{20}$

"Sesungguhnya Allah tidak akan mengampuni perbuatan syirik, dan akan mengampuni selain dari itu bagi siapa saja yang Dia kehendaki. Dan barang siapa menyekutukan Allah (syirik), maka sesungguhnya dia telah membuat dosa besar." (QS. al-Nisā' [4]: 48)

"Sesungguhnya syirik itu merupakan kezaliman yang besar." (QS. alLuqmān [31]: 13)

Lawan Tauhid selain syirik adalah paham yang meniadakan sama sekali adanya Tuhan, yaitu ateisme. Menurut Islam, aliran ateisme adalah suatu kekafiran paling besar, musuh manusia yang terang-terangan. Tuhan mengancamnya dengan hukuman yang paling dahsyat pula. Firman Allah swt: ${ }^{21}$

"Sesungguhnya orang-orang kafir itu adalah musuh kamu yang paling nyata." (QS. al-Nisā' [4]: 101)

Dari Ānas ra. dia berkata: Saya mendengar Rasulullāh saw bersabda: Allah swt berfirman: "Wahai anak Adam, sesungguhnya engkau berdoa kepada$\mathrm{Ku}$ dan memohon ampun kepada-Ku, maka akan Aku ampuni engkau, Aku tidak peduli (berapa pun banyaknya dan besarnya dosamu). Wahai anak Adam seandainya dosa-dosamu (sebanyak) awan di langit kemudian engkau minta ampun kepada-Ku, niscaya akan Aku ampuni engkau. Wahai anak Adam, sesungguhnya jika engkau datang kepada-Ku dengan kesalahan sepenuh bumi kemudian engkau menemuiku dengan tidak menyekutukan Aku sedikit pun, maka akan Aku temui engkau dengan sepenuh itu pula ampunan." (HR. al-Turmudhī dan dia berkata: hadisnya hasan shahih)

Pengetahuan tentang Tuhan hanya mungkin diperoleh secara pasti apabila melalui pemberitaan wahyu (revelation). Pengetahuan itu mustahil didapat dengan pemikiran akal semata, mengapa? Karena pikiran manusia lemah (da'if) untuk menjangkau masalah ketuhanan kalau ia hanya berjalan sendirian. Pikiran manusia sifatnya nisbi, sedangkan Tuhan sifatnya mutlak (absolut). ${ }^{22}$

Mungkin saja pikiran manusia dapat mengenal Tuhan dengan jalan pemikiran filsafat, dengan menelaah dan merenungkan terhadap alam semesta yang melingkungi hidupnya atau terhadap dirinya sendiri, seperti hasil yang didapat oleh Socrates (470-399 SM) dan Aristoteles (384-322 SM). Dengan pemikiran filsafat mereka menemukan Tuhan, yang diistilahkan oleh Aristoteles sebagai "sebab pertama". Akan tetapi, Tuhan yang mereka temukan itu dengan jalan filsafat semata, berakhir dengan lumpuhnya Tuhan itu, karena Tuhan 
yang ia temukan itu selanjutnya tidak berfungsi. Dia menemukan lalu meyakini adanya Tuhan, tetapi keyakinan itu kemudian menjadi mati, karena dia tidak bisa membuktikan imannya di dalam keseluruhan hidupnya, padahal iman itu harus dibuktikan. Pembuktiannya ialah dengan jalan menyembah dan mengabdi kepada-Nya. Tuhan memiliki undang-undang yang harus dipatuhi, perintah-perintah yang wajib dilaksanakan, tapi juga ada larangan-laranganNya yang harus dijauhi. Dapatkah manusia dengan akalnya semata mengenai semua ini lengkap dengan sistem iman dan ibadah yang beanr. Mustahil, jawab akal itu sendiri. Semua itu hanya dapat dikenal dengan pasti melalui wahyu. ${ }^{23}$

Begitu juga kelumpuhan Tuhannya kaum Deisme. Tuhan aliran ini hanya sekadar Tuhan, bukan faktor yang aktif dalam kehidupan sehari-hari. Ia tidak perlu disembah dan ditaati perintahNya. Dapatkah seorang hanya dengan percaya saja, tidak dengan patuh dan tunduk?

Islam mengajarkan bahwa kepercayaan atau iman seseorang haruslah dibuktikan dengan jalan melaksanakan penyembahan (ibadah) dan menaati segala hukum-hukum Tuhan (syari'ah) yang telah digariskan lewat wahyuwahyuNya yang diturunkannya kepada Rasulullah. Maka pelaksanaan ibadah dan syari'at adalah manifestasi dari iman seseorang. Kemudian konsep kepercayaan dengan segala perintah dan larangan Tuhan hanya mungkin ditemukan dalam agama. Sebab itu realisasi yang benar dari keyakinan kepada Tuhan ialah melakukan ibadah sesuai dengan yang dikehendaki oleh Tuhan itu sendiri. ${ }^{24}$

Doktrin Tauhid bagi kehidupan manusia, menjadi sumber kehidupan jiwa dan pendidikan kemanusian yang tinggi. Tauhid akan mendidik jiwa manusia untuk mengikhlaskan seluruh hidup dan kehidupannya kepada Allah semata. Tujuan hidupnya ialah Allah dan harapan yang dikejarya ialah keridhaan Allah (mardhätilläh). Hal ini membawa konsekuensi pada pembinaan karakter yang agung, menjadi manusia yang suci, jujur, dan teguh memegang amanah, yang akhirnya melahirkan insan kamil. Maka Tauhid merupakan kekuatan yang besar yang mampu mengatur secara tertib manusia yang berjutajuta yang hidup tersebar di laut dan di darat, dan tepi-tepi pantai hingga ke bukit-bukit. ${ }^{25}$ Tauhid juga akan membebaskan manusia dari seribu satu macam belenggu kejahatan duniawi. Tauhid membebaskan manusia dari penjajahan, perbudakan dan perhambaan, baik oleh sesama manusia, maupun oleh hawa nafsu dan harta benda. Karena dengan tauhid, manusia hanya akan menghambakan diri kepada Allah semata.

Dengan jiwa tauhid yang tinggi, seseorang akan bebas dari belenggubelenggu ketakutan dan duka-cita dalam kemiskinan harta benda, karena yakin bahwa tiap binatang melata di bumi ini dari Tuhan jualah rezekinya. Kewajiban 
bagi manusia ialah bekerja dan berusha sambil berdoa, hasilnya di tangan Tuhan sendiri. Tauhid juga membebaskan manusia dari ikatan-ikatan kuris, kedudukan, dan jabatan. Sebab Tauhid menyadarkan manusia bahwa hanya Tuhanlah yang dapat menaik-turunkan seseorang dari kursi dan jabatannya. Dan Tuhan berkuasa memuliakan atau menghinakan seseorang, Allah swt. adalah sumber segala kemuliaan: "Barang siapa yang menghendaki kemuliaan, maka bagi Allah-lah segala kemuliaan itu.” (QS. Fāṭir [35]: 10).

Tauhid juga membebaskan manusia dari perasaan takut mati. Tauhid menyadarkan manusia bahwa persoalan mati adalah di tangan Tuhan, dan setiap yang berjiwa pasti mengalami mati. Mati adalah pintu gerbang yang setiap makhluk akan lewat di pintu gerbang itu. Konsekuensinya menumbuhkan semangat jihad seseorang untuk menegakkan yang hak dan menghancurkan yang batil, sekalipun ia harus menyabung nyawa dan mempertaruhkan jiwa raga. Jadi, seorang muslim harus memiliki keberanian: berani berpihak kepada kebenaran dan keadilan, berani hidup juga berani mati demi keagungan Allah swt.

Akhirnya, Tauhid akan membebaskan manusia dari perasan keluh-kesah, bingung menghadapi persoalan hidup dan keputus-asaan. Dengan Tauhid, seorang muslim memiliki jiwa besar, tidak berjiwa kerdil, memiliki jiwa yang agung dan tenang (tuma'ninah). Jadi, Tauhid memberikan kebahagiaan hakiki kepada manusia di dunia dan kebahaiaan abadi di akhirat kelak. Karena itu, pendidikan tauhid sangat penting bagi manusia, terutama bagi generasi muda yang merupakan cermin dan harapan masa datang.

Buku daras ini mendiskusikan tauhid teoritis dan aplikatif. Bagaimana tauhid dicerna secara intelektual dan dapat langsung dipraktikkan dalam hidup sehari-hari. Tetapi ajaran tauhid yang hanya disajikan dalam empat (4) halaman ini terlihat tidak eksploratif, tidak mendiskusikan secara luas pandangan para ulama ahli Ilmu Kalam, apakah Sunni, Muktazilah atau Syiah. Malah secara sekilas ia hanya menyebut model-model tauhid: Uluhiyah dan Rububiyah, suatu pembagian yang sebenarnya lazim didiskusikan dalam paham Wahabisme.

\section{Pemahaman dan Penerapan Hukum Islam}

Buku daras juga mendiskusikan satu bab khusus tentang Hukum Islam: pengertian, sumber dan lain-lain. Di sini saya akan mendiskusikan secukupnya saja. Seperti dipahami umumya, Hukum Islam adalah hukum yang bersumber dan merupakan bagian dari ajaran Islam. Ada dua istilah yang berhubungan dengan hukum Islam. Pertama, al-Sharìah, kedua al-Fiqh. Syari'at merupakan 
hukum Islam yang ditetapkan secara langsung dan tegas oleh Allah. Sementara fikih merupakan hukum yang ditetapkan pokok-pokoknya saja. Hukum ini dapat atau perlu dikembangakan dengan ijtihad, hasil pengembangannya inilah yang kemudian dikenal dengan istilah fikih. ${ }^{26}$

Hukum Islam kategori syari'at bersifat konstan, tetap, maksudnya tetap berlaku di sepanjang zaman, tidak mengenal perubahan dan tidak boleh disesuaikan dengan situasi dan kondisi. Situasi dan kondisilah yang menyesuaikan dengan syari'at. Sedangkan hukum Islam kategori fikih bersifat fleksibel, elastis, tidak (harus) berlaku universal, mengenal perubahan, serta dapat disesuaikan dengan situasi dan kondisi. ${ }^{27}$

Dalam kehidupan sehari-hari, kedua istilah itu (syariat dan fikih) dirangkum dalam istilah hukum Islam. Hal ini dapat dipahami karena keduanya sangat erat hubungannya, dapat dibedakan tetapi tidak dapat dipisahkan. Syari'at merupakan landasan fikih, dan fikih merupakan pemahaman orang (yang memenuhi) tentang syariat. Oleh karena itu, seseorang yang akan memahami hukum Islam dengan baik dan benar harus dapat membedakan antara syari'at Islam dengan fikih Islam. Pada prinsipnya syari'at adalah wahyu Allah yang terdapat dalam al-Qur'an dan sunag Rasul. Syari'at bersifat fundamental, mempunyai ruang lingkup yang lebih luas dari fikih, berlaku abadi dan menunjukkan kesatuan dalam Islam. Sedangkan yang dimaksud fikih adalah pemahaman manusia yang memenuhi syarat tentang syari'at yang sekarang terdapat dalam kitab-kitab fikih. Oleh karena itu, fikih bersifat instrumental, ruang lingkupnya terbatas pada hukum yang mengatur perbuatan mansia, yang biasanya disebut perbuatan hukum. Karena fikih adalah hasil karya manusia, maka ia tidak berlaku abadi, dapat berubah dari masa ke masa, dapat berbeda dari satu tempat dengan tempat yang lain. Hal ini terlihat pada aliran-aliran hukum yang disebut dengan istilah mazhab-mazhab. Oleh karena itu, fikih menunjukkan adanya keragaman dalam hukum Islam. ${ }^{28}$

Fikih merupakan penjelasan dari syari'at yang terang serta pemahaman dan penggalian terhadap kandungan syari'at yang masih samar. Sebagaimana diuraikan di atas, fikih senantiasa berubah. Karena sifatnya yang berubah-ubah itu, fikih biasanya disandarkan kepada ulama mujtahid yang memformulasikannya, seperti fikih Hanafí, Shāfìì. Hanbālī, Mālikī, dan sebagainya. Sedangkan syari'at senantiasa disandarkan kepada Allah dan Rasul-Nya. ${ }^{29}$

Mengenai sifat hukum Islam, Mohammad Tahir Azhary mengemukakan tiga sifat hukum Islam, yakni: pertama, bidimensional, artinya mengandung segi kemanusiaan dan segi ketuhanan. Di samping itu, sifat bidimensional yang dimiliki hukum Islam juga berhubungan dengan sifatnya yang luas atau kom- 
prehensif. Hukum Islam tidak hanya mengatur satu aspek kehidupan saja, tetapi mengatur berbagai aspek kehidupan manusia. Kedua, adil, yakni mempunyai hubungan yang erat sekali degan sifat bidimensional. Dalam hukum Islam, keadilan bukan saja merupakan tujuan, tetapi merupakan sifat yang melekat sejak kaidah-kaidah dalam syari'at ditetapkan. Keadilan merupakan sesuatu yang didambakan oleh setiap manusia baik sebagai individu maupun masyarakat. Ketiga, individualistik dan kemasyarakatan yang diikat oleh nilainilai transendental, yaitu wahyu Allah yang disampaikan kepada Nabi Muhammad saw. Dengan sifat ini, hukum Islam memiliki validitas baik bagi perorangan maupun masyarakat. ${ }^{30}$

Hukum Islam, baik dalam pengertian syari'at maupun fikih membahas dua lapangan bidang pembahasan, yakni bidang ibadah dan bidang muamalah. Bidang ibadah membahas tata cara dan upacara yang wajib dilakukan seorang muslim dalam berhubungan dengan Allah, seperti menjalankan shalat, puasa, menunaikan zakat, dan melaksanakan haji. Adapun mu'amalah dalam pengertian luas adalah ketetapan Allah yang langsung berhubungan dengan kehidupan sosial manusia walaupun ketetapan itu terbatas pada yang pokok-pokok saja seperti perdagangan, pernikahan, kesehatan dan sebagainya. Oleh karena itu, sifatnya terbuka untuk dikembangkan melalui ijtihad (pemikiran) manusia yang memenuhi syarat untuk melakukan hal itu. ${ }^{31}$

Buku daras kemudian menyebut tiga (3) sumber hukum Islam, yakni alQur'an, Sunnah, dan Ijtihad, yang terdiri atas Ijma', Qiyas, Istislāḥ, Istiḥsan, 'Urf, Sadd Dara'i, Istisḥab, Mazhab Șaḥabī, dan Syar'un man Qablana. Pengertian dari istilah-istilah ini bisa dibaca pada buku-buku Ushul Fikih konvensional. Secara umum, pembahasan soal Hukum Islam ini mengacu kepada polapola yang sudah ada, yang biasa dirujuk, dengan model Sunni secara umum (bukan mazhab tertentu), tetapi yang jelas tidak mengacu kepada model hukum Islam Syi'ah atau kepada para sarjana Hukum Islam yang dianggap "liberal" seperti 'Abdullāh Aḥmad al-Naim, Maḥmūd Muḥammad Ṭāhā, atau Shaḥrūr dengan teori Syariah "batas minimal" dan "batas maksimal" atau hukum prioritas dan non-prioritas, dan paham-paham yang semacam dengan mereka.

\section{Kerukunan dan Kebersamaan dalam Pluralitas Agama}

Tema berikutnya adalah soal kerukunan dan pluralitas agama. Pada era globalisasi sekarang ini, umat beragama dihadapkan kepada serangkaian tantangan baru yang tidak terlalu berbeda dengan yang pernah dialami sebelumnya. Pluralitas agama adalah fenomena nyata yang ada dalam kehidupan. Pluralitas merupakan hukum alam (sunnatullah) yang tidak mungkin terelak- 
kan. Ia sudah merupakan kodrat dalam kehidupan. Surat al-Hujurāt [49]: ayat 13 yang menggambarkan adanya pluralitas sudah cukup kuat mengindikasikan semangat pluralitas itu. ${ }^{32}$

Namun, pluralitas tidak semata menunjukkan pada kenyataan tentang adanya kemajemukan, tetapi lebih dari itu, perlu adanya keterlibatan aktif terhadap kenyataan adanya pluralitas tersebut. Pluralitas agama dapat kita jumpai di mana-mana. Di dalam masyarakat tertentu, di kantor terdapat bekerja, di pasar tempat belanja, bahkan di perguruan tinggi tempat belajar. Seseorang baru dikatakan memiliki sikap keterlibatan aktif dalam pluralitas apabila dia dapat berinteraksi secara positif dalam lingkungan yang majemuk tersebut. Dengan kata lain, pemahaman pluralitas agama menuntut sikap pemeluk agama untuk tidak hanya mengakui keberadaan dan hak agama lain, tetapi juga terlibat dalam usaha memahami perbedaan dan persamaan guna tercapai kerukunan dan kebersamaan. ${ }^{33}$

Dalam mewujudkan kerukunan dan kebersamaan dalam pluralitas agama, QS. al-Nahl [16]: ayat 125 menganjurkan dialog dengan baik. Dalam dialog, seorang Muslim hendaknya menghindari mengklaim dirinya sebagai orang yang berada dalam pihak yang benar, tapi dengan menunjukkan bukti sehingga orang lain bisa melihat kenyataan akan kebenaran Islam. Dialog tersebut dimaksudkan untuk saling mengenal dan saling menimba pengetahuan tentang agama kepada mitra dialog. Dialog tersebut dengan sendirinya akan memperkaya wawasan kedua belah pihak dalam rangka mencari persamaan-persamaan yang dapat dijadikan landasan untuk hidup rukun dalam kehidupan bermasyarakat. ${ }^{34}$

Kerukunan dan kebersamaan yang didambakan dalam Islam bukanlah yang bersifat semu, tetapi yang memberi rasa aman pada jiwa setiap manusia. Oleh karena itu, langkah pertama yang dilakukan adalah mewujudkannya dalam setiap diri individu, setelah itu melangkah pada unit terkecil pada masyarakat, yakni keluarga, lalu beralih ke masyarakat luas, seterusnya kepada seluruh bangsa di dunia ini. Dengan demikian dapat tercipta kerukunan, kebersamaan, dan perdamaian dunia.

Itulah ajaran pluralitas dalam Islam. Kalau pun kenyataan berbeda dengan konsep ideal, bukan berarti konsep ajarannya yang salah, tetapi pelaku atau manusianyalah yang dipersalahkan.

Buku daras tidak berani menggunakan istilah "pluralisme agama" sebagai istilah yang sensitif, yang biasa dipahami sebagai "menyamakan semua agama", dan karena itu telah difatwakan haram oleh MUI pada 2006. Dengan istilah "pluralitas agama" buku daras hanya ingin mengajak mahasiswa mengakui fakta kemajemukan agama, menghormatinya dan bersikap aktif dalam merayakan 
perbedaan. Tiga hal ini sudah dianggap bagian pokok dari sikap kerukunan umat beragama. Dengan mencukupkan pada hal-hal tersebut, jelaslah bahwa buku daras menghindari mendiskusikan secara akademik terminologi pluralisme agama sebagai diskursus teologi yang cukup rumit, yang harus mendiskusikan filsafat perennial, dan terminologi Trilogi Kerukunan yang dulu dipopulerkan oleh Departemen Agama di bawah Alamsyah Ratu Perwiranegara. Buku daras sebenarnya hanya menyuguhkan suatu "kata pengantar" saja yang dapat lebih mudah dipahami oleh mahasiswa semester pertama.

\section{Misi Perdamaian dan Kerahmatan Islam Bagi Seluruh Alam}

Membicarakan materi Islam, tokoh Islam atau Lembaga Islam biasanya akan menyertakan pembahasan soal Islam raḥmatan lil-álamin, termasuk buku daras ini. Seperti biasa, yang pertama dirujuk adalah pengertian etimologis Islam. Kata Islam berarti damai, selamat, sejahtera, penyerahan diri, taat, dan patuh. Pengertian tersebut menunjukkan bahwa agama Islam adalah agama yang mengandung ajaran untuk menciptakan kedamaian, keselamatan, dan kesejahteraan kehidupan umat manusia pada khususnya, dan semua makhluk Allah pada umumnya. Kondisi ini akan terwujud apabila manusia sebagai penerima amanah Allah dapat menjalankan aturan tersebut secara benar dan "kaffah"."

Agama Islam adalah agama yang Allah turunkan sejak manusia pertama, Nabi pertama, yaitu Nabi Adam. Agama Islam itu kemudian Allah turunkan secara berkesinambungan kepada para Nabi dan Rasul-rasul berikutnya. Akhir dari proses penurunan agama Islam itu baru terjadi pada masa kerasulan Muhammad saw. pada awal abad ke-7 Masehi. Islam sebagai nama dan agama yang Allah turunkan belum dinyatakan secara eksplisit pada masa kerasulan sebelum Muhammad saw., tetapi makna dan substansi ajarannya secara implisit memiliki persamaan yang dapat dipahami dari penyataan sikap para Rasul, sebagaimana firman Allah: "Dan Ibrähìm telah mewasiatkan ucapan itu kepada anak-anaknya, demikian pula Ya'qüb. (Ibrähìm berkata): Hai anak-anakku, sesungguhnya Allah telah memilih agama ini bagimu, maka janganlah kamu mati kecuali dalam keadaan Islam." (QS. al-Baqarah [2]: 132).

Ajaran Islam memiliki karakteristik sebagai berikut: ${ }^{37}$

1. Inti ajarannya adalah "tauhidullah" dan seluruh ajarannya mencerminkan ketauhidan Allah tersebut.

2. Sesuai dengan fitrah hidup manusia, artinya: a). ajaran Islam mengandung petunjuk yang sesuai dengan sifat dasar manusia, baik dari aspek keyakinan, perasaan, maupun pemikiran; b). sesuai dengan 
kebutuhan hidup manusia; c). memberikan manfaat tanpa menimbulkan komplikasi; dan d). menempatkan manusia dalam posisi yang benar. Kondisi itu ditegaskan oleh Allah dalam QS. al-Rūm [30]: 30.

3. Ajarannya sempurna, artinya materi ajaran Islam berisi petunjukpetunjuk pada seluruh kehidupan manusia. Petunjuk itu adakalanya disebut secara eksplisit, dan adakalanya secara implisit. Untuk memahami petunjuk yang bersifat implisit dilakukan dengan ijtihad. Penegasan tentang kesempurnaan ajaran Islam itu dijelaskan dalam QS. alMāidah [5]: 3.

4. Kebenaran mutlak, artinya kebenaran itu dapat dipahami karena ajaran Islam berasal dari Allah Yang Maha Benar, dan dapat pula dipahami melalui bukti-bukti materil, serta bukti riilnya. Karena itu Allah mengingatkan agar manusia tidak meragukan kebenarannya, sebagaimana difirmankan dalam QS. al-Baqarah [2]: 147.

5. Mengajarkan keseimbangan dalam berbagai aspek kehidupan. Sekalipun menurut ajaran Islam manusia diciptakan hanya untuk beribadah kepada Allah, tetapi nilai ibadah manusia terdapat pada seluruh aspek kehidupan, dan manusia harus memerhatikan berbagai aspek-aspek kepentingan dalam hidupnya tersebut, sebagaimana Allah disebutkan dalam QS. al-Qaṣaș [28]: 77.

6. Berlaku secara universal, artinya ajaran Islam berlaku untuk seluruh umat manusia di dunia sampai akhir masa. Penegasan tersebut dinyatakan oleh Allah dalam QS. al-Aḥzāb [33]: 40.

7. Sesuai dengan akal pikiran dan memotivasi manusia untuk menggunakan akal pikirannya sebagaimana dijelaskan dalam QS. Mujādilah [58]: 11 .

8. Fleksibel dan ringan, artinya ajaran Islam memerhatikan dan menghargai kondisi masing-masing individu dalam menjalankan aturannya dan tidak memaksakan kepada orang Islam untuk melakukan suatu perbuatan di luar batas kemampuannya. Hal itu ditegaskan oleh Allah dalam QS. al-Baqarah [2]: 286.

9. Menciptakan rahmat, kasih sayang Allah terhadap makhlukNya, seperti ketenangan hidup bagi orang yang meyakini dan menaatinya. Hal itu dinyatakan oleh Allah dalam QS. al-Fath [48]: 4. Kerahmatan yang diwujudkan oleh Islam itu juga dinyatakan Allah ketika menjelaskan misi kerasulan Muhammad saw., sebagaimana terdapat dalam QS. al-Anbiyā̄ [21]: 107. 
Buku daras ini hanya menyuguhkan beberapa ayat al-Qur'an yang menunjukkan kerahmatan Islam untuk makhluk semesta tanpa mendiskusikan lebih lanjut hadis-hadis Nabi Muhammad, contoh perilaku Nabi dan contoh historis para Khalifah yang menunjukkan komitmen yang kuat terhadap ajaran rahmatan lil-'älamīn, serta banyak penjelasan dan contoh-contoh konkret lainnya yang dapat menyentuh dan menggugah mahasiswa untuk dapat menghayati dan mempraktikkan model Islam sebagai rạ̣matan lil-älamīn. Dengan kata lain, pembahasan soal ini sangat normatif belaka.

\section{Lesbian, Gay, Biseksual dan Transgender (LGBT)}

Salah satu isu dalam diskursus isu-isu keislaman kontemporer adalah soal LGBT (lesbian, gay, biseksual dan transgender) yang juga menjadi bahasan di antara dosen dan mahasiswa UB. Seorang dosen tetap PAI bernama Mokhamad Rozikin M.Pd menulis satu buku berjudul "LGBT Dalam Tinjauan Fikih" (2017). Buku itu diberi Kata Pengantar oleh Dekan Fakultas Kedokteran UB, Dr. dr. Sri Andarini, M.Kes. Dalam kata pengantarnya Andarini menulis bahwa ia menyambut baik buku karya Rozikin, sebagai dosen PAI di Fakultas Kedokteran. Artinya, buku itu kemudian menjadi salah satu buku ajar PAI di samping buku daras yang telah disepakati. Tetapi rupanya, tanpa sepengetahuan para koleganya dosen PAI, Rozikin juga mewajibkan buku tersebut sebagai buku ajar wajib untuk para mahasiswa Fakultas Ilmu Budaya (FIB) UB semester satu/ganjil 2018 kelas A, B, dan C. Berdasarkan pengakuan dua mahasiswa FIB yang kami wawancarai, buku daras PAI UB hanya diperkenalkan kepada mahasiswa, dibahas beberapa bab pokok seperti tauhid dan hukum Islam, tetapi kemudian proses pengajaran berfokus pada buku LGBT. Setelah UTS hingga UAS buku wajib yang dibaca adalah buku LGBT. Mahasiswa diberi tugas UTS untuk meresume buku tersebut, lalu diwajibkan untuk mengupload di media sosial hasil resume tersebut, yang tentu saja opini negatif tentang LGBT dari sisi ajaran Islam.

Buku LGBT terdiri atas enam (6) bab, yakni Pendahuluan, liwāt (homoseksual), sihāq (lesbianisme), takhannūth (banci) dan tarajjul (tomboy), Taubat dari LGBT, dan Penutup. Menurut Rozikin, pengertian liwāt adalah "perbuatan kaum Lūṭ." "Al-liwāt dinamakan demikian karena yang pertama kali melakukannya adalah kaum Lūṭ". ${ }^{38}$ Dengan mengutip Kitab al-Hāwī al-Kabìr adalah "seorang lelaki menyetubuhi laki-laki". Dalam Kitab Mu'jam Lughat alFuqahä' disebutkan bahwa liwāt adalah "orang yang melakukan perbuatan kaum Lūt, yakni menyetubuhi laki-laki pada anusnya”. Rozikin juga mengutip Kitab al-Fawākih al-Dawānì karya Imam Nafroni yang menyatakan bahwa 
liwāt adalah "membenamkan khasyafah (ujung penis pria) pada anus seorang laki-laki". ${ }^{39}$ Jadi jelaslah bahwa liwāt bukan sekedar hasrat atau perasaan suka seorang lelaki terhadap lelaki lain (sejenis) tetapi sudah mela-kukan hubungan intim sejenis dengan cara sodomi.

Rozikin kemudian mengutip beberapa ayat al-Qur'an yang mengisahkan perbuatan umat nabi Lūṭ sebagai "perbuatan keji" (fähishah) [QS. Al-A'rāf [7]: 80) dan musrifün (kaum yang melampaui batas) [QS. al-A'rāf [7]: 81). ${ }^{40}$ Perbuatan liwät jelas hukumnya haram secara mutlak. Para pelakunya akan dilaknat oleh Allah. Rozikin menyebut beberapa hadis, antara lain "Allah melaknat orang yang melakukan perbuatan kaum Lūṭ” nabi mengulang-ulang perkataan ini sampai tiga kali. Dari 'Amri Ibn Abī 'Amr Nabi bersabda "Terlaknatlah orang yang melakukan perbuatan kaum nabi Lūṭ". Dari Ibn 'Abbās Rasulullah bersabda "Allah tidak akan melihat seorang lelaki yang menyetubuhi lelaki lain (homoseksual) atau menyetubuhi wanita dari dubur-nya”. ${ }^{41}$ Jadi menurut Rozikin, jelaslah bahwa perbuatan liwāt adalah keji, terkutuk dan para ulama sudah sepakat sebagai "dosa besar".

Lalu bagaimana dengan sanksi liwäț? Rozikin merujuk kepada pendapat para ulama, antara lain Imam Mālik, al-Shāfììi, Aḥmad dan al-Mawardī melalui karyanya al-Hawi al-Kabìr sepakat bahwa liwät termasuk hadd yang harus dihukum dengan dicambuk atau dirajam. ${ }^{42}$ Meskipun liwāt tidak masuk kategori zina, tetapi liwāt adalah termasuk dosa sangat berat yang dikutuk Allah sehingga Allah menimpakan azab yang sangat pedih kepada kaum nabi Lūt dengan cara kota Sodom diangkat, dibalikkan dan dihancurkan sampai binasa semua penduduknya. Pendapat lain seperti Imam Abū Hanifah menyatakan bahwa liwāt tidak perlu dihukum dengan hadd, tetapi cukup dengan ta'zir. Alasannya, semua perbuatan yang tidak bisa disebut zina, maka tidak wajib dihukum dengan hadd, termasuk istimta' dīn al-jimä' (bercumbu yang tidak sampai bersetubuh). ${ }^{43}$

Menurut Rozikin lebih lanjut, sekelompok ulama berpendapat bahwa sanksi pelaku liwät harus dibunuh secara mutlak tanpa membedakan apakah pelakunya mubsan (sudah menikah) atau bukan mubșan. Semuanya harus dibunuh, baik pelaku liwāt aktif (yang berperan sebagai lelaki) maupun pelaku liwāt pasif (yang berperan sebagai wanita). Menurut Rozikin, ini adalah pendapat Abū Bakar al-Ṣiddīq, 'Alī Ibn Abī Ṭālib, Ibn 'Abbās, Khalīd Ibn Walīd, 'Abdullāh Ibn Zubayr, Jābir Ibn Zayd, 'Ubaidillāh Ibn 'Abdillāh Ibn Ma'mar, al-Zuhrī, Rabī’ah Ibn Abī 'Abd al-Raḥmān, al-Qasim Ibn Ibrāhīm, al-Nașīr, Mālik, Aḥmad, Isḥāq Ibn Rahawaih, al-Ajuri, Ibn Taymiyyah, Ibn Qayyim Jawziyah, Ibn Rajab, al-Shawkānī, al-Ṣan'ānī, 'Abdullāh Ibn Bāz, dan Ibn 
'Uthaymin. Ketika mengutip nama-nama ini, Rozikin merujuk kepada karyakarya Ibn Taymiyyah, Ibn Qayyim, Ibn Bāz, 'Uthaymin, dan al-Ṣan'ānī. Para ulama di atas kemudian dikutip oleh Rozikin pandangan-pandangan mereka bahwa pelaku liwāt "harus dibunuh" tanpa ampun. ${ }^{44}$

Rozikin kemudian menyebut beberapa hadis Nabi yang menyatakan "Barangsiapa melakukan perbuatan kaum Lūț, maka bunuhlah" "Bunuhlah pelaku (liwāt) subyek (aktif) dan obyeknya (pasif)", dan hadis-hadis lain. ${ }^{45}$ Rozikin juga mengutip pendapat al-Albānī bahwa perintah membunuh para pelaku liwāt adalah riwayat shahih. ${ }^{46}$ Menurut Rozikin, semua riwayat (hadis dan pendapat para ulama) yang ia sajikan, baik yang merekomendasikan hukum bunuh secara mutlak, atau yang merekomendasikan hukum bunuh dengan cara dirajam, semuanya semakin menguatkan bahwa sanksi liwāṭ adalah dibunuh. ${ }^{47}$

Tetapi cukup aneh sebenarnya, Rozikin pada paragraf yang sama merujuk kepada pendapat al-Syawkānī yang menyatakan "meskipun sanad-sanad riwayat di atas diperbincangkan karena da'if (lemah), tetapi secara keseluruhan saling menguatkan sehingga bisa dijadikan dalil. Al-Shawkānī mengatakan "Riwayat ini secara keseluruhan bisa digunakan sebagai hujjah (dalil)". 48 Jadi, sebenarnya Imam Syaukani yang dirujuk oleh Rozikin sudah mengakui bahwa "riwayatriwayat sanksi terhadap liwāt adalah da'if”. Meskipun semua riwayat da' if itu dikumpulkan, apakah kemudian valid dan sah untuk dijadikan dalil atau pengambilan hukum?

Lalu bagaimana cara membunuhnya? Menurut Rozikin, berdasar pendapat para ulama, maka ada enam (6) cara membunuh pelaku liwāt: dirajam, dibunuh dengan pedang kemudian dibakar, dibakar api, dijatuhkan dari tempat tinggi, dijatuhi reruntuhan tembok, dan dipenjara di tempat busuk. ${ }^{49}$

Pada bab tiga (III) Rozikin membuat ulasan mengenai siḥāq, yakni perbuatan lesbi. Pelaku lesbi atau sihāq tidak bisa disamakan dengan liwät, sehingga tidak bisa dikenai sanksi liwāt. Perbuatan ini juga bukan digolongkan jenis zina, sehingga tidak bisa dikenai sanksi zina. Perbuatan ini adalah perbuatan maksiat yang jelas melanggar banyak nasss yang menunjukan keharamannya. Hanya saja, tidak ada teks khusus yang menjelaskan bentuk sanksinya, sehingga maksiat ini termasuk jenis maksiat yang tidak ada hadd-nya dan juga tidak ada kaffarah-nya. Maksiat jenis ini, menurut Rozikin, harus dihukum dengan hukuman bentuk ta'zir karena perbuatan ini juga semakna dengan perbuatan mubāsharah dīn al-farji (bercumbu tidak sampai bersetubuh), mengingat sihāq tidak mengandung unsur ilaj (memasukkan kelamin). ${ }^{50}$

Kemudian, Rozikin menyebut istilah takhannüth dan tarajjul alias banci alias laki-laki yang menyerupai perempuan atau sebaliknya (tomboy). Menurut 
Rozikin, sanksi bagi pelaku takhonnuts yang dibuat-buat/takalluf bukan hadd atau kaffarah karena tidak ada nașs khusus yang menjelaskan kadar tertentu untuk menghukum perilaku tersebut. Karenanya, sanski maksiat ini adalah jenis ta'zir sebagaimana yang diperintahkan dan dilakukan Rasulullah saat mengusir dan mengasingkan para mukhannäth (banci). Al-Baihāqī meriwayatkan "Dari Ibnu 'Abbās bahwasnnya Nabi bersabda "Usirlah orang-orang banci dari rumah kalian!". ${ }^{51}$ Menurut Rozikin, tertulis dalam kitab al-Bahrür-Ra-iq bahwa "Mukhannäth adalah orang yang melakukan perbuatan buruk yang tidak halal baginya berdasarkan kesepakatan karena ia sebagaimana orang-orang fasiq yang lain, maka dia harus dijauhkan dari para wanita." 52

Menurut Rozikin, di Madinah ada mukhannāth yang bernama Anah. Disebutkan bahwas Nabi mengasingkannya ke suatu daerah bernama Hamrä' al-Asād. Ada pula mukhannäth lain yang bernama Matī’ yang juga diasingkan. Imam al-Nawāwī menyatakan bahwa Nabi mengasingkan Matī' dan Hit ke daerah al-Hima." Ibnu Hajar juga menginfokan bahwa Anjasyah, seorang budak hitam mukhannäth yang bersuara merdu dan suka bernyanyi dengan memakai sya'ir wanita, telah diasingkan Nabi. Al-'Asqalānī berkata: "Nabi mengusir Anjasyah dan Umar mengusir fulan. Anjasyah adalah budak hitam yang berdendang dengan memakai pakaian para wanita." ${ }^{53}$

Cukup "mengerikan" membaca buku LGBT dengan ulasan yang sepenuhnya 'tekstual'. Rozikin, yang menempuh S-1 dan S-2 dalam bidang Pendidikan Bahasa Arab, sama sekali tidak menganalisis berbagai konteks tentang bagaimana teks-teks, apakah hadis dan lebih banyak pendapat ulama, diproduksi saat itu, konteksnya bagaimana, dan bagaimana dipahami dalam konteks sekarang. Apakah saat ini masih relevan bahwa kaum homoseksual harus dimusnahkan dengan cara dibunuh dengan enam cara? Apakah kaum lesbi dan banci harus dicambuk, dirajam atau diusir dari tempat tinggalnya? Bagaimana orang menjadi homo, lesbi atau banci? Apakah mereka masih punya hak untuk tinggal dan hidup? Hal-hal kontekstual lainnya yang tidak didiskusikan oleh Rozikin. Buku teks itu sepenuhnya bersifat sangat normatif.

Ketika saya dan asisten peneliti mendiskusikan buku LGBT tersebut dengan Inamul Wafi dan Kahlid Rahman selaku pengurus dan mantan pengurus PPA, mereka sangat kaget bahwa buku tersebut menjadi buku daras kedua dan setiap dua orang mahasiswa wajib membelinya. Semua tim dosen yang lain tak pernah diberitahu bahwa buku tersebut menjadi buku acuan mahasiswa. Wafi dan Rahman kembali menegaskan bahwa sesuai kesepakatan semua tim dosen PAI UB bahwa buku ajar panduan mereka hanyalah buku daras yang dicetak oleh UB Press yang diketuai oleh Prof. Thohir Luth. Bahwa buku 
LGBT karya Rozikin itu telah diterbitkan oleh UB Press, tim dosen semuanya mengetahuinya, tetapi mereka merasa "kecolongan" bahwa buku tersebut menjadi buku wajib kedua bagi para mahasiswa. Jadi, buku LGBT itu semacam 'deviasi' atau 'penyimpangan' dari regulasi dan kesepakatan tentang 'buku daras wajib'.

Mengapa buku LGBT itu menjadi buku referensi yang diwajibkan oleh Rozikin? Pertama, isu LGBT, dalam lima tahun terakhir, menjadi diskursus sosial-keagamaan yang paling aktual dan paling menyedot perhatian publik, termasuk tokoh-tokoh agama. Dalam konteks inilah Rozikin ingin terlibat dalam melakukan kontekstualisasi dan aktualisasi pengajaran PAI di UB. Kedua, penting dicatat bahwa model Pendidikan agama Islam di perguruan tinggi umum --secara umum-- termasuk UB, adalah memperkuat iman dan bersifat konservatif. Sedikit sekali porsi critical thinking dalam proses pembelajaran. LGBT sendiri dimusuhi oleh hampir semua agama, besar dan kecil. Dalam konteks konservatisme pengajaran PAI inilah Rozikin menganggap sangat penting mengajarkan LGBT dalam perspektif Islam demi menyelamatkan umat Islam dari praktik LGBT dan murka Tuhan. Saya menduga, berdasarkan wawancara, sebagian besar dosen PAI tidak setuju dengan praktik LGBT, mungkin juga mereka 'membenci' praktik LGBT. Tetapi, dalam hal mengajak mahasiswa memusuhi LGBT melalui sebuah buku ajar, saya tidak yakin mereka akan menyetujui dengan apa yang dilakukan oleh Rozikin.

Meski demikian, ada suatu fenomena yang menarik. Walaupun sebagian besar dosen PAI yang merasa moderat dan tidak setuju dengan konten buku LGBT yang diindoktrinasikan kepada mahasiswa, pihak Rektorat dan pimpinan Universitas sudah membuat draft SK yang melarang penyebaran paham radikalisme, terorisme dan LGBT. Artinya, jika SK tersebut kelak disahkan maka buku LGBT karya Rozikin akan menemukan justifikasi, relevansi dan urgensinya bagi pembelajaran PAI di masa depan, dan segera kita membayangkan para mahasiswa produk buku tersebut menjadi "bengis" dan "intoleran" terhadap eksistensi kaum LGBT. Buku itu juga bertentangan dengan demokrasi yang dianut Indonesia dan tidak sejalan dengan "nilai-nilai dan pendidikan kewargaan" (civic education) yang mengusung kesetaraan semua warga bangsa (Indonesia).

\section{Pandangan Para Dosen tentang Isu-Isu Kontemporer}

Selain membaca dan menganalisis tema isu-isu kontemporer dalam buku daras, saya juga berkesempatan mewawancarai dan menggali pandangan para dosen PAI UB terkait pandangan-pandangan yang mungkin tidak termaktub dalam buku daras. Ada dua hal pokok yang kami diskusikan, pertama soal 
korupsi, dan kedua soal minoritas. Pertama, korupsi. Muhajir dan Sugeng Santoso memandang bahwa melihat persoalan korupsi harus adil dan obyektif. Tidak bisa dikatakan bahwa mayoritas Muslim adalah koruptor dan nonMuslim sedikit melakukan korupsi. Santoso secara lebih tegas menyatakan bahwa masyarakat Indonesia disuguhi informasi oleh media massa yang tidak adil dan sepihak, misalnya selalu menyebut bahwa Ahok adalah pejabat yang bersih, padahal belum tentu seperti itu. Karena media massa dikuasai nonMuslim, maka konten berita dan informasi sering menyudutkan mayoritas muslim. Menurut Muhajir dan Santoso, soal korupsi sebenarnya bukan soal uang semata, tetapi banyak aspek. Dalam mencegah dan melawan sikap koruptif ini, keduanya selalu menekankan kepada mahasiswa --dalam mengajar- untuk memperkuat akidah dan akhlak. Dalam mendiskusikan dan melawan praktik korupsi, Khalid Rahman mempraktikkan dalam proses perkuliahan. Setiap mahasiswa dilihat berapa menit ia terlambat datang ke kelas. Nanti dihitung akumulatif dan bisa dianggap tidak masuk jika sudah sampai satu jam setengah. Dengan cara ini Rahman mendidik mahasiswa untuk tidak korupsi waktu. Dalam diskusi di kelas, Rahman dan mahasiswa juga berkesimpulan bahwa hukuman untuk para koruptor tidak berat dan tidak membuat efek jera, sehingga praktik korupsi bukan berhenti tapi terus berkembang dengan beragam modus. Meskipun di penjara, para koruptor tetap menikmati kekayaannya dan kenyamanannya di penjara. Dari diskusi korupsi kemudian berkembang kepada soal jinayät dan qișas. Karena banyak kahsus hokum yang tidak adil, Rahman setuju jika qișaș dan Jinayat dapat masuk ke dalam hukum positif, semata-mata demi keadilan dan efek jera.

Kedua, soal minoritas. Soal minoritas yang jadi perdebatan di kelas juga menjadi perhatian serius para dosen. Tema-tema seputar ini biasanya adalah eksistensi Ahmadiyah, Syiah, pendirian rumah ibadah non-Muslim, keselamatan non-Muslim di akhirat, dan pemimpin publik non-Muslim. Ketika mendiskusikan topik-topik ini, dosen memberi respons beragam. Soal kelompok minoritas, Rohmah dan Muhajir menginginkan bahwa semua pihak harus menghormati dan meyakini eksistensi mereka dengan cara dialog dan silaturahmi, tidak dengan mempersekusi atau menyalahkan mereka. Menurut Muhajir, di Indonesia enam agama resmi diakui. Harus menghormati semua aspek keyakinan, ritual dan ajaran agama mereka. Hubungan sosial Muslim dan nonMuslim harus mengacu kepada ajaran Islam tentang ukhuwwah insāniyyah. Untuk soal Ahmadiyah dan Syiah, hanya Santoso yang mengembalikan soal itu kepada fatwa MUI dan undang-undang atau peraturan pemerintah yang berlaku. Menurut Santoso, cara yang elegan dalam soal minoritas Muslim adalah 
kembali kepada fatwa MUI tentang hal-hal tersebut. Dalam soal pembangunan rumah ibadah, kelima dosen sepakat untuk mengikuti aturan perundanganundangan yang telah ditetapkan.

Setelah menggali lebih lanjut, sebenarnya beberapa dosen memiliki pandangan keagamaan yang "agak konservatif" alias "kurang terbuka". Misalnya karena tidak setuju dengan eksistensi Ahmadiyah, Syiah atau pembangunan rumah ibadah non-Muslim, mereka mengembalikan masalah itu kepada fatwa MUI dan peraturan pemerintah yang sudah jelas "membatasi" untuk tidak disebut "diskriminatif" terhadap kelompok minoritas. Cara beberapa dosen tersebut mengembalikan persoalan akademik di kelas kepada fatwa Lembaga dan peraturan pemerintah jelas merupakan cara yang paling aman daripada mengungkapkan opini keagamaannya sendiri, mengingat jumlah mahasiswa yang sangat banyak dengan paham/aliran keagamaan yang sangat beragam. Meski demikian, beberapa dosen yang lain terlihat benar-benar sebagai akademisi yang inklusif, bahkan pluralis, seperti Siti Rohmah yang tidak mempersoalkan nonMuslim menjadi pemimpin publik, atau Inamul Wafi yang punya pandangan kesejarahan kontekstual yang sangat positif terhadap kebhinekaan dan kelompok minoritas.

Akhirnya, dalam soal radikalisme dan terorisme, jelaslah bahwa mereka semua memusuhi kedua hal tersebut dan mengajak para mahasiswa untuk tidak jadi Muslim radikal, misalnya gampang mengkafirkan sesama Muslim yang berbeda atau menolak ideologi negara dan mengkampanyekan Khilafah. Bahkan, dalam soal ini, pihak Rektorat/Pimpinan Universitas telah menyiapkan SK Rektor (2018) yang berisi Penolakan/Permusuhan terhadap RadikalismeTerorisme dan kaum LGBT, yang harus menjadi acuan para dosen dan seluruh Civitas Akademika UB. Tetapi hingga awal 2019 SK tersebut belum juga disahkan.

\section{Model Pengajaran}

Beberapa dosen memiliki model pengajaran yang beragam. Ahmad Muhajir misalnya, lebih menekankan pembelajaran PAI untuk memperkuat iman, moral/akhlak dan penguatan ubudiyah. Hal ini karena sebagian besar mahasiswa baru berasal dari SMU yang kurang mengenal agama Islam dengan baik. Bagi mahasiswa baru dari sekolah umum "berpikir kritis tak ada gunanya". Penguatan moral, iman dan ubudiyyah ini mencapai hampir 80\%. Sisanya 20\% baru bisa diajak berfikir kritis, jika memungkinkan. Sugeng Santoso juga melakukan hal serupa. Yang pokok adalah akhlak, 'ubüdiyah dan karakter. Berpikir kritis tambahan saja. Siti Rohmah lain lagi. Di awal pertemuan yang 
lebih ditekankan adalah tauhid dan akidah Islam. Setelah selesai UTS, barulah Rohmah banyak mendiskusikan soal-soal "critical thinking", dan dalam beberapa kasus menugaskan mahasiswa untuk "studi kasus di lapangan". Studi lapangan ini, menurut Rohmah, disesuaikan dengan kondisi Fakultas yang beragam. Wafi juga memakai model memperkuat iman, tetapi aspek historis (asbāb al-nuzūl) dari banyak aspek ajaran Islam ditekankan, supaya mahasiswa tahu konteks historis-kultural. Kadang-kadang beberapa ajaran Islam dikomparasikan dengan agama dan keyakinan non-Islam semata komparasi akademik. Aspek critical thinking (CT) belum bisa diberikan, paling banyak hanya 25\%, karena waktu sudah habis membicarakan materi-materi yang konvensional. Menurut Wafi, mahasiswa Prodi Humaniora dan Ilmu Sosial biasanya standar dan normal saja, tidak terlalu kritis. Menurut Wafi lebih lanjut, mahasiswa Jurusan Eksakta memang ingin mengetahui "kepastian" agama lebih mendalam, lebih jelas, lebih pasti, lebih Qurani dan sunah, lebih hitam-putih. Wafi meyakini bahwa 40\% mahasiswa Jurusan Eksakta itu cenderung memiliki pemahaman Islam yang radikal. Terdapat Empat dosen: Muhajir, Santoso, Rohmah dan Wafi melakukan model perkuliahan yang hampir sama, yakni wajib presentasi bagi mahasiswa, dan sebagian besar bersifat ceramah dari dosen karena khawatir diskusi mahasiswa melenceng dari materi ajar.

Berbeda dengan empat dosen di atas, Khalid Rahman malah lebih menekankan critical thinking (CT) daripada model normatif. Model CT ini mencapai 70\%. Menurut Rahman, model pembelajaran ceramah, doktriner dan tidak kritis, tidak saja tidak menarik bagi mahasiswa, tapi juga membuat mereka bosan, karena model itu sudah sejak dari kecil mereka rasakan. Mereka lebih antusias dengan model CT yang berbentuk "studi kasus". Tetapi memang, menurut Rahman, hal itu tergantung pada Fakultas-fakultas yang berbeda. Fakultas Ilmu Eksakta misalnya, lebih menyukai model doktriner yang hitam putih daripada CT. Tetapi Fakultas Ilmu-ilmu sosial dan Humaniora lebih antusias dengan model CT. Jurusan sastra Cina misalnya, ditugaskan Rahman untuk mencari penyebab mengapa Islam tidak berkembang di Cina, padahal Islam datang lebih dulu ke Cina daripada Indonesia, dan di Cina ada kuburan Sahabat, Sa'ad Ibn Abī Waqqaṣ. Mengapa justru Islam berkembang di Indonesia? Menurut Rahman, ternyata makalah-makalah mahasiswa bagus sekali. Mereka serius. Mereka menemukan terdapat beberapa Dinasti di Cina yang tidak suka kepada Islam dan "menghadang" pertumbuhan komunitas Muslim. Rahman juga memberi tugas lapangan untuk melihat dan mengawasi Perda-perda dan keadaan masyarakat miskin misalnya, dan sejauh mana pimpinan/kepala daerah "blusukan" sebagaimana dipraktikkan oleh para Khalifah yang amanah dulu. 
Hasil pengamatan didiskusikan di kelas. Mahasiswa lebih banyak bicara sampai $60 \%$, dan dosen mengarahkan hingga 40\%. Tetapi menurut Rahman ada kekecualian. Bagi mahasiswa yang lemah dalam materi CT, Rahman memberi ceramah dan tugas/paper studi pustaka.

Mahasiswa di Fakultas Humaniora dan Ilmu-Ilmu Sosial biasanya memiliki pemahaman yang umum dan standar dan tidak terlalu kritis untuk lebih mendalam karena sudah memaklumi akan kebudayaan dan kemajemukan Indonesia. Tetapi para mahasiswa Fakultas Eksak (termasuk Kedokteran), mereka ingin mengetahui lebih mendalam, lebih pasti, lebih hitam-putih karena akan dijadikan pandangan dan keyakinan yang pasti (kaku). Secara umum buku teks PAI yang resmi dan diajarkan sudah cukup mendorong para mahasiswa untuk bersikap toleran dan terbuka, tetapi belum cukup kuat melawan radikalisme. Harus ada penekanan yang kuat dari para dosen (ketika mengajar) untuk melawan paham-paham keagamaan yang tertutup dan radikal. Menurut penjelasan Inamul Wafi dan Khalid Rahman, organisasi terlarang HTI mendapat anggota terbanyak di Fakultas MIPA dan Kedokteran, tetapi materi-materi keislaman mereka diperoleh dari kegiatan keislaman yang banyak tersebar di kampus dan bukan dari materi ajar resmi PAI di bawah koordinasi PPA. Di kedua Fakultas ini juga banyak dosen-dosen anggota HTI tapi bukan dosen PAI. Sekitar 40\% mahasiswa dan dosen yang berafiliasi ke HTI.

\section{Materi/Konten Pengajaran}

Seperti telah disebut, materi ajar mengacu kepada Buku Daras Pendidikan Agama Islam UB RPS yang telah ditetapkan. Semua dosen PAI wajib mengacu kepada buku daras dan RPS itu. Beberapa dosen ada yang menambahkan referensi yang lain, misalnya Rojikin mewajibakan karyanya, LGBT menjadi buku wajib bagi para mahasiswa. Beberapa referensi digunakan untuk memperkuat atau menambah perspektif atas buku daras. Muhajir, Wafi, Santoso dan Rohmah misalnya menggunakan antara lain: dalam bidang tauhid/akidah adalah buku-buku tentang Aswaja, kitab Aqidah Tahäwiyah, dalam bidang Fikih adalah Fikih Sayyid Sabiq, Fikih empat mazhab, dalam bidang Tafsir adalah Tafsìr Ibn Kathīr, dalam bidang hadis adalah Kitab Ṣahīḥ al-Bukhärī dan Muslim, 'Arba' al-Nawāwī, dan Kitāb al-Mughnī, dan dalam bidang Akhlak adalah Kitab Tazkiyat al-Nufüs. Sedangkan Rahman menggunakan buku-buku Pemikiran Politik Islam dari masa klasik hingga modern, History of Arab Philip Hitti, 'Ābid al-Jabirī, Kritik Nalar Arab, buku-buku Islam kritis Hassan Hanafī,

Arkoun, Fazlur Raḥmān, dan Karen Armstrong. Rahman juga membaca Das Kapital Karl Marx, Nietsczhe dan Muhammad Iqbal. Untuk referensi Arab, 
Rahman membaca Ushul Fikih, 'Ulūm al-Qur'ān dan 'Ulüm al-Hadìth. Secara umum, model pengajarannya adalah mendeskripsikan semua mazhab teologi dan fikih, dosen tidak memaksakan ideologi/paham keagamaannya (karena UB adalah universitas umum negeri milik publik), dan dosen telah berusaha untuk lebih menekankan para mahasiswa agar memiliki sikap toleran dan terbuka karena dalam Islam terdapat banyak paham dan mazhab.

\section{Kesimpulan}

Membaca buku teks/daras PAI UB memunculkan beberapa kesimpulan menarik. Pertama, secara umum banyak sekali aspek atau materi dalam buku daras yang mendorong mahasiswa bersikap terbuka, menghormati kemajemukan dan bersikap toleran terhadap orang lain dengan paham/mazhab yang berbeda. Hal ini --seperti telah disinggung di atas-- ditegaskan oleh para dosen PAI dengan alasan karena UB adalah perguruan tinggi umum negeri milik publik dan karena dalam Islam sendiri memang terdapat banyak paham dan mazhab yang berbeda-beda. Semangat inklusifisme, kosmopolit dan toleransi terlihat eksplisit dalam buku daras PAI UB dan menjadi visi para dosen PAI. Jika terjadi penyimpangan dari buku daras tersebut atau ada ideologi tertutup, ideologi takfiri yang intoleran, ideologisasi Islam yang melawan NKRI, maka bisa dipastikan hal itu karena "inisiatif dosen" secara personal, dan tidak mewakili Lembaga PPA. Tetapi, sejauh ini, tidak ditemukan 'inisiatif dosen' PAI dengan ideologi-ideologi tertutup itu. Kedua, dengan demikian, sama sekali tidak ditemukan konten pengajaran agama Islam dalam buku daras yang mendorong para mahasiswa untuk menjadi radikal atau teroris. Radikal dalam pengertian suka terlibat mengkafirkan sesama Muslim yang berbeda, mengkampanyekan Wahabisme atau Islamisme yang menjadikan Islam sebagai ideologi tertutup, atau menolak ideologi negara dan mengkampanyekan Khilafah. Konten buku daras, baik eksplisit maupun implisit, tidak mengandung bibitbibit radikalisme, apalagi terorisme. Penting dicatat juga bahwa hampir semua dosen tetap PAI bermazhab Teologi Sunni, yang secara umum memiliki pandangan dan sikap keagamaan yang moderat, kecuali dalam kasus "Buku LGBT" Rojikin. Pada umumnya, para dosen itu adalah alumni dan produk IAIN/UIN yang sejak awal memang memiliki tradisi studi dan praktik Islam yang moderat. Ketiga, riset ini merekomendasikan kepada PPA agar buku daras itu (jika perlu) diperkuat oleh diskursus kesarjanaan Islam klasik, apakah ilmu kalam, tasawuf, siyasah Islam, atau perdebatan mazhab-mazhab Fikih, yang sebenarnya dapat membuka cakrawala mahasiswa, bukan saja kekayaan khazanah intelektual Islam, tetapi juga menginspirasi dan mempengaruhi mereka tentang semangat 
"keterbukaan" dan "kekayaan perbedaan" dalam Islam. Buku daras tersebut adalah hasil olahan atau rekonstruksi Tim penulisnya yang sudah dinarasikan dalam bungkus 'konteks modern dan popular' saat ini. Kedalaman materimateri kesarjanaan Islam kurang tajam, atau kurang terasa. Keempat, meskipun buku daras PAI UB sudah mengandung semangat inklusifisme, kosmopolitanisme dan toleransi, tetapi riset ini merekomendasikan kepada PPA agar materi buku daras memperkuat atau mempertajam dirinya dalam melawan intoleransi, radikalisme dan terorisme. Kelima, terkait dengan "buku LGBT" versi Rozikin, riset ini merekomendasikan kepada PPA agar "mengevaluasi" atau "mempertimbangkan" kembali buku tersebut sebagai buku ajar alternatif mengingat secara sosio-politik Indonesia adalah negara demokrasi, memiliki UU HAM dan menjunjung tinggi nilai-nilai civic education yang intinya adalah bahwa semua warga negara memiliki hak hidup yang dijamin konstitusi, memiliki hak untuk setara, dan memiliki hak untuk menentukan hidupnya. UB sendiri adalah Lembaga Pendidikan negeri milik publik. Jika buku LGBT itu terus diajarkan, maka produk yang dihasilkan adalah kebencian dan permusuhan terhadap sesama warga bangsa.

\section{Catatan Akhir}

${ }^{1}$ Mukti Ali, Ilmu Perbandingan Agama di Indonesia (Bandung: Mizan, 1988), 19-20.

${ }^{2}$ Thohir Luth, dkk., Buku Daras Pendidikan Agama Islam (Malang: Pusat Pembinaan Agama (PPA) Universitas Brawijaya, 2015), vii.

${ }^{3}$ Paristiyanti Nurwardani dkk, Pendidikan Agama Islam untuk Perguruan Tinggi (Jakarta: Direktorat Pembelajaran Dirjen PK Kemristek Dikti RI, 2016), iii.

${ }^{4}$ Thohir Luth, dkk., Buku Daras Pendidikan Agama Islam, 1.

${ }^{5}$ Luth, dkk., Buku Daras Pendidikan Agama Islam, 1.

${ }^{6}$ Luth, dkk., Buku Daras Pendidikan Agama Islam, 1-2.

${ }^{7}$ Luth, dkk., Buku Daras Pendidikan Agama Islam, 2.

${ }^{8}$ Luth, dkk., Buku Daras Pendidikan Agama Islam, 2.

${ }^{9}$ Luth, dkk., Buku Daras Pendidikan Agama Islam, 3.

${ }^{10}$ Luth, dkk., Buku Daras Pendidikan Agama Islam, 3.

${ }^{11}$ Luth, dkk., Buku Daras Pendidikan Agama Islam, 4.

${ }^{12}$ Luth, dkk., Buku Daras Pendidikan Agama Islam, 4-5.

${ }^{13}$ Luth, dkk., Buku Daras Pendidikan Agama Islam, 5.

${ }^{14}$ Luth, dkk., Buku Daras Pendidikan Agama Islam, 5.

${ }^{15}$ Luth, dkk., Buku Daras Pendidikan Agama Islam, 5-6.

${ }^{16}$ Luth, dkk., Buku Daras Pendidikan Agama Islam, 6.

${ }^{17}$ Luth, dkk., Buku Daras Pendidikan Agama Islam, 10. 
${ }^{18}$ Luth, dkk., Buku Daras Pendidikan Agama Islam, 43.

${ }^{19}$ Luth, dkk., Buku Daras Pendidikan Agama Islam, 43-44.

${ }^{20}$ Luth, dkk., Buku Daras Pendidikan Agama Islam, 44.

${ }^{21}$ Luth, dkk., Buku Daras Pendidikan Agama Islam, 44.

${ }^{22}$ Luth, dkk., Buku Daras Pendidikan Agama Islam, 45.

${ }^{23}$ Luth, dkk., Buku Daras Pendidikan Agama Islam, 45-46.

${ }^{24}$ Luth, dkk., Buku Daras Pendidikan Agama Islam, 46.

${ }^{25}$ Luth, dkk., Buku Daras Pendidikan Agama Islam, 46-47.

${ }^{26}$ Luth, dkk., Buku Daras Pendidikan Agama Islam, 117.

${ }^{27}$ Luth, dkk., Buku Daras Pendidikan Agama Islam, 117-118.

${ }^{28}$ Luth, dkk., Buku Daras Pendidikan Agama Islam, 118.

${ }^{29}$ Luth, dkk., Buku Daras Pendidikan Agama Islam, 118.

${ }^{30}$ Luth, dkk., Buku Daras Pendidikan Agama Islam, 118-119.

${ }^{31}$ Luth, dkk., Buku Daras Pendidikan Agama Islam, 119.

${ }^{32}$ Luth, dkk., Buku Daras Pendidikan Agama Islam, 192.

${ }^{33}$ Luth, dkk., Buku Daras Pendidikan Agama Islam, 192.

${ }^{34}$ Luth, dkk., Buku Daras Pendidikan Agama Islam, 192-193.

${ }^{35}$ Luth, dkk., Buku Daras Pendidikan Agama Islam, 181.

${ }^{36}$ Luth, dkk., Buku Daras Pendidikan Agama Islam, 181.

${ }^{37}$ Luth, dkk., Buku Daras Pendidikan Agama Islam, 181.

${ }^{38}$ M.R. Rozikin, LGBT dalam Tinjauan Fikih, Menguak Konsepsi Islam Terhadap Lesbian, Gay, Biseksual, dan Transgender (Malang: UB Press, 2017), 15.

${ }^{39}$ Rozikin, LGBT dalam Tinjauan Fikih, 17.

${ }^{40}$ Rozikin, LGBT dalam Tinjauan Fikih, 20.

${ }^{41}$ Rozikin, LGBT dalam Tinjauan Fikih, 22-23.

${ }^{42}$ Rozikin, LGBT dalam Tinjauan Fikih, 70.

${ }^{43}$ Rozikin, LGBT dalam Tinjauan Fikih, 72.

${ }^{44}$ Rozikin, LGBT dalam Tinjauan Fikih, 73-75.

${ }^{45}$ Rozikin, LGBT dalam Tinjauan Fikih, 76.

${ }^{46}$ Rozikin, LGBT dalam Tinjauan Fikih, 79.

${ }^{47}$ Rozikin, LGBT dalam Tinjauan Fikih, 77.

${ }^{48}$ Rozikin, LGBT dalam Tinjauan Fikih, 77.

${ }^{49}$ Rozikin, LGBT dalam Tinjauan Fikih, 80.

${ }^{50}$ Rozikin, LGBT dalam Tinjauan Fikih, 175.

${ }^{51}$ Rozikin, LGBT dalam Tinjauan Fikih, 201.

${ }^{52}$ Rozikin, LGBT dalam Tinjauan Fikih, 203.

${ }^{53}$ Rozikin, LGBT dalam Tinjauan Fikih, 205.

\section{Daftar Pustaka}

Ali, Mukti. Ilmu Perbandingan Agama di Indonesia. Bandung: Mizan, 1988.

Khotimah, Perbandingan Agama: Pengantar Sutudi Memahami Agama-Agama, Pekanbaru: ASA RIU, 2015. 
Al-Kumayi, Sulaiman. Islam Bubuhan Kumai: Perspektif Varian Awam, Nahu, dan Hakekat. Semarang: Pustaka Zaman, 2011.

Lidinillah, Mustofa Anshori Dkk, (ed.), Pendidikan Agama Islam: Buku Teks untuk Perguruan Tinggi Umum Berdasarkan Kurikulum Tahun 2002, Yogyakarta: Badan Penerbitan Filsafat UGM, 2006.

Luth, Thohir, dkk. Buku Daras Pendidikan Agama Islam. Malang: Pusat Pembinaan Agama (PPA) Universitas Brawijaya, 2015.

Muhtadi, Pendidikan Agama Islam pada Perguruan Tinggi, Jakarta: PT. Mandala Nasional, 2016.

Nasution, Syamruddin. Arbitrase Menjadi Penyebab Timbulnya Sekte-Sekte dalam Islam, Pekanbaru: Yayasan Pusaka Riau, 2011.

Nurwardani, Paristiyanti dkk. Pendidikan Agama Islam untuk Perguruan Tinggi. Jakarta: Direktorat Pembelajaran Dirjen PK Kemristek Dikti RI, 2016.

Rozikin, M.R. LGBT dalam Tinjauan Fikih, Menguak Konsepsi Islam Terhadap Lesbian, Gay, Biseksual, dan Transgender. Malang: UB Press, 2017.

Schuon, Frithjof. Mencari Titik Temu Agama-Agama, Jakarta: Pustaka Firdaus, 2003.

Wawancara dengan Inamul Wafi, Malang 12 Desember 2018

Wawancara dengan Ahmad Muhajir, Malang 13 Desember 2018.

Wawancara dengan Sugeng Santoso, Malang 13 Desember 2018.

Wawancara dengan Khalid Rahman, Malang 13 Desember 2018.

Wawancara dengan Siti Rohmah, Malang 13 Desember 2018. 